\title{
Post harvest loss and marketing of fruits - economic analysis of pink flesh guava in local and distant markets in India
}

\author{
*T.M. Gajanana, D. Sreenivasa Murthy, M. Sudha, A.K. Saxena \\ D.V.Sudhakar Rao and V. Dakshinamoorthy \\ ICAR-Indian Institute of Horticultural Research, Bengaluru - 560089 \\ *Email : Gajanana.TM@icar.gov.in
}

\begin{abstract}
Guava produced in Bengaluru in Karnataka is also transported to distant markets like Cochin in Kerala and Chennai in Tamil Nadu. An assessment of post harvest loss (PHL) was done in these markets. The main marketing channel followed was:
\end{abstract}

$$
\text { Producer } \rightarrow \text { PHC } \rightarrow \text { Distant Market WS Retailer } \rightarrow \text { Consumer }
$$

Marketing practices followed in marketing of pink flesh guava and losses occurring at the wholesale (transit) and retailers' level (storage) in the distant market - Kerala were studied from wholesalers and retailers. The PHL at the wholesalers' level was observed to be 3.6 per cent mainly due to pressed and crushed fruits during transit. The retail level loss was 4.59 per cent which was mainly due to storage for more than two days resulting in decaying, rotting, yellowing etc. Average price received by the wholesaler was Rs.29.92/kg with a margin of $\mathrm{Rs.6.21} / \mathrm{kg}(20.75 \%)$. The retailers received a price of Rs.46.54/kg with a margin of Rs.16.35/kg (35.13\%). Marketing practices followed in marketing of pink flesh guava and losses occurring at the wholesale (transit) and retailers' level (storage) in the distant market - Chennai (Tamil Nadu) were studied with wholesalers in Coimbeedu market and retailers in different parts of Chennai. The PHL at the wholesalers' level was observed to be 4.62 per cent mainly due to pressed and crushed fruits during transit. The retail level loss was 6.09 per cent which was due to pressing of fruits during handling. The wholesaler received a margin of 22.91 percent in trading of guava fruits. The retailers received a margin of $\mathbf{4 5 . 7 2}$ per cent. The Karnataka farmers can take advantage of the higher prices prevalent in the distant markets and increase their income. Pathological investigation indicated that losses occurred at different stages of handling due to Styler end rot, Anthracnose, Canker, thrips attack etc., which needs to be addressed. The storage losses of pink flesh guava were estimated as $5.89 \%$ after 4 days of storage at room temperature $\left(24-32{ }^{\circ} \mathrm{C}\right)$ that constituted mainly the physiological loss in weight (PLW). Spoilage started after 5 days of storage $(10.5 \%)$ and reached to $28.31 \%$ by 6 days of storage. After 4 days of storage, guava fruits lose weight to the extent of 6 per cent and the spoilage starts after 5 days. Hence, care should be taken to dispose of the fruits within five days of harvest.

Key words: Post harvest loss, marketing, pink flesh guava, economic analysis

\section{INTRODUCTION}

Guava (Psidium gujava $\mathrm{L}$ ) is an important nutritious fruit crop in the country and accounts for about 4 per cent each of area and production of total fruit crops in India. There are two different types of guava viz. Allahabad safeda (White flesh) and Pink flesh. While information on economic aspects of marketing and the losses that occur at different stages of handling of Allahabad safeda guava is available
[Gajanana et al. 2011; Gajanana et al. 2015], the same for pink flesh guava is lacking at present. Hence, a study to examine the marketing arrangements and to assess the post harvest losses in pink flesh guava at different stages of handling, both at local market and distant markets, was undertaken in one of the major guava producing states, Karnataka, of India. 


\section{DATA AND METHODOLOGY}

Karnataka is one of the major guava producing states in the country and it produces 1397703 tonnes (3.81\%) from an area of 6858 ha. (2.56\%). About 15 per cent of guava in Karnataka is produced in Bangalore (Rural and Urban) districts accounting for 15 per cent of the state area under guava (2013-14). Pink flesh guava is a popular variety used both for table and processing purposes besides being rich in lycopene content and is grown in Karnataka. As Bangalore (Rural \& Urban) district produces the maximum quantity of this type of guava in the state, Bangalore district was selected for the study. Data was collected from 19 sample farmers in Bangalore North taluk and 15 retailers from markets. Guava produced in Bangalore is also marketed in distant markets like Cochin in Kerala and Chennai in Tamil Nadu. Hence, efforts were made to assess the transit and retail level losses in these markets also. Averages, percentages and ratios were used as analytical tools.

\section{RESULTS}

\section{Marketing practices in Pink flesh guava}

Guava harvesting fields in Bangalore district were visited. Marketing practices followed and losses occurring at the field and retailers' levels were studied. The main marketing channel followed by the guava growers in Bangalore district was Field Sale of guava to contractors/processors. Specifically, the following channels are observed:

\section{Producer $\rightarrow$ Local Market $C A \rightarrow$ Retailer $\rightarrow$ Consumer}

2. Producer $\rightarrow$ PHC $\rightarrow$ Local Market $C A \rightarrow$ Retailer $\rightarrow$ Consumer

3. Producer $\rightarrow$ PHC $\rightarrow$ Processor

4. Producer $\rightarrow$ PHC $\rightarrow$ Distant Market WS $\rightarrow$ Retailer $\rightarrow$ consumer

\section{Post harvest loss assessment in pink flesh guava in the local market}

Total post harvest loss (PHL) in pink flesh guava worked out to 17.06 per cent consisting of field level loss of 11.47 per cent and retail level loss of 5.59 per cent (Table $\mathbf{1}$ ).

Table 1. Post harvest loss in guava at different levels of handling - Bangalore market

\begin{tabular}{|l|l|c|}
\hline Sl. No. & Stages/levels & Loss (\%0 \\
\hline 1 & $\begin{array}{l}\text { Field level } \\
\text { (after harvest and before marketing - } \\
\text { grading, sorting for damages) }\end{array}$ & 11.47 \\
\hline & Damage due to canker & 4.43 \\
\hline & Over ripe fruits and discarded & 4.16 \\
\hline & Damage due to bird attack & 0.93 \\
\hline & Damage due to blossom (Styler) end rot & 0.54 \\
\hline 2 & Damage due to mealy bug, scratches, malformation etc & 1.41 \\
\hline 3 & $\begin{array}{l}\text { Retail market level } \\
\text { damage due to press \& crushed fruits } \\
\text { during transit \& loading/ unloading) }\end{array}$ & 5.59 \\
\hline & Total PHL in guava & 17.06 \\
\hline
\end{tabular}

PHL at field level: Total PHL in pink flesh guava at the field level was observed to be 11.47 per cent consisting of canker affected fruits $(4.43 \%)$, over ripe fruits $(4.16 \%)$, bird attack $(0.93 \%)$, blossom end rot $(0.54 \%)$, scratches, mealy bug, malformation and other diseases $(1.41 \%)$.
PHL at retail level: Retail level losses worked out to5.59 per cent mainly consisting of press damaged and crushed fruits during handling.

Price realization: Average price received by the farmer was Rs.25.38/kg in the local Bangalore market with a producer share of 73.54 per cent. The retailers 
realized a price of Rs. $31.25 / \mathrm{kg}$ with a margin of Rs.5.45/kg (21.12\%).

Pathological investigation of causes of damage: Guava (Pink Flesh) fruits collected from the orchards located in different localities were assessed for the association of different diseases. The overall percent disease incidence varied from $26.67 \%$ (locality 4 ) to $50.00 \%$ (locality-1). Among the diseased fruits Anthracnose (Colletotrichum gloeosporiodes), Styler end rot (Phomopsis psidi) and canker (Pestaliopsis psidi) were the major diseases that resulted in spoilage of fruits and their level varied in different localities (Tables 2 \& 3). Anthracnose was the major disease followed by Styler end rot and Canker in localities no 1,2,3,4 \& 6 where the incidence of Anthracnose ranged from $52.78 \%$ (locality-6) to $38.33 \%$ (locality-1); Styler end rot varied from $38.89 \%$ (locality no-6) to $35.56 \%$ (locality-2) whereas Canker ranged from $22.22 \%$ (locality no 1 ) to $27.78 \%$ (locality no 4). Similarly Canker was a major problem followed by Styler end rot and Anthracnose in localities-3 \& 5. Here, incidence of Canker was $50.00 \%$ in locality-3 and $41.67 \%$ in locality-5; Incidence of Styler end rot was $30.56 \%$ in both the localities whereas incidence of Anthracnose ranged from $19.44 \%$ (locality -3 ) to $27.78 \%$ (locality-5). In localities-7\& 8, Styler end rot was the major problem followed by Canker and Anthracnose. Incidence of Styler end rot, Canker and Anthracnose were $57.78 \%$ $\& 38.33 \% ; 35.67 \%$ \& $31.67 \%$ and $6.67 \% \& 30.00 \%$ in localities $7 \& 8$ respectively.

Table 2. Status of guava (Pink flesh) fruits collected from different localities

\begin{tabular}{|c|c|c|c|c|c|c|c|c|}
\hline \multirow{2}{*}{ Fruit Status } & \multicolumn{8}{|c|}{ Localities } \\
\cline { 2 - 9 } & 1 & 2 & 3 & 4 & 5 & 6 & 7 & 8 \\
\hline \multirow{2}{*}{ Healthy (\%) } & 50.00 & 63.33 & 53.33 & 73.33 & 66.67 & 66.67 & 66.67 & 56.67 \\
\cline { 2 - 9 } & $(45.01)$ & $(52.87)$ & $(46.93)$ & $(59.02)$ & $(54.79)$ & $(54.79)$ & $(55.09)$ & $(48.85)$ \\
\hline \multirow{2}{*}{ Diseased (\%) } & 50.00 & 36.67 & 46.67 & 26.67 & 33.33 & 33.33 & 33.33 & 43.33 \\
\cline { 2 - 9 } & $(45.01)$ & $(37.15)$ & $(43.09)$ & $(31.00)$ & $(35.22)$ & $(35.22)$ & $(34.93)$ & $(41.16)$ \\
\hline
\end{tabular}

Note: Figures in parentheses indicate Angular transformed values

Table 3. Incidence of diseases on guava (Pink flesh) fruits collected from different localities

\begin{tabular}{|l|c|c|c|c|c|c|c|c|}
\hline Disease & \multicolumn{10}{|c|}{ Localities } \\
\hline & 1 & 2 & 3 & 4 & 5 & 6 & 7 & 8 \\
\hline Canker & 27.22 & 28.89 & 50.00 & 27.78 & 41.67 & 8.33 & 35.56 & 31.67 \\
(Pestaliopsis psidi) & $(31.46)$ & $(32.52)$ & $(45.01)$ & $(31.81)$ & $(40.21)$ & $(16.78)$ & $(36.61)$ & $(34.25)$ \\
\hline Styler end rot & 34.44 & 35.56 & 30.56 & 33.33 & 30.56 & 38.89 & 57.78 & 38.33 \\
(Phomopsis psidi) & $(35.94)$ & $(36.61)$ & $(33.56)$ & $(35.27)$ & $(33.56)$ & $(38.59)$ & $(49.48)$ & $(38.26)$ \\
\hline Anthracnose & 38.33 & 35.56 & 19.44 & 38.89 & 27.78 & 52.78 & 6.67 & 30.00 \\
(C.gloeosporioides) & $(38.26)$ & $(36.61)$ & $(26.17)$ & $(38.59)$ & $(31.81)$ & $(46.60)$ & $(14.97)$ & $(33.22)$ \\
\hline \multicolumn{10}{|c|}{ C.D. (0.5\%) $=9.778$} \\
\hline
\end{tabular}

Note: Figures in parentheses indicate Angular transformed values

Post harvest storage losses in Pink Flesh guava fruits: The storage losses of pink flesh guava were estimated as $5.89 \%$ after 4 days of storage at room temperature $\left(24-32^{\circ} \mathrm{C}\right)$ that constituted mainly the physiological loss in weight (PLW). Spoilage started after 5 days of storage (10.5\%) and reached to 28.31 $\%$ by 6 days of storage. By storing the fruits at low temperature of $12^{\circ} \mathrm{C}$, the total storage losses after 12 days could be reduced to $8.99 \%$ that constituted 6.99 $\%$ of PLW and $2.07 \%$ of spoilage. The total storage losses at $12^{\circ} \mathrm{C}$ increased to $16.56 \%$ when the storage duration increased to 15 days. The spoilage during storage at both room temperature and $12^{\circ} \mathrm{C}$ was found to be mainly due to anthracnose disease (Table 4). 
Table 4. Post harvest storage losses in Pink Flesh guava fruits stored at RT and $12^{\circ} \mathrm{C}$

\begin{tabular}{|l|c|c|c|c|c|c|c|c|}
\hline & \multicolumn{4}{|c|}{ Physiological Loss in Weight (PLW) \% } & \multicolumn{5}{c|}{ Spoilage (\%) } \\
\hline & \multicolumn{4}{|c|}{ Days after Harvest } & \multicolumn{4}{c|}{ Days after Harvest } \\
\hline \multirow{2}{*}{$\begin{array}{l}\text { At Room } \\
\text { Temperature }\end{array}$} & 2 & 4 & 5 & 6 & 2 & 4 & 5 & 6 \\
\hline \multirow{2}{*}{ At $12^{\circ} \mathrm{C}$} & 2.95 & 5.89 & 8.35 & 9.98 & 0 & 0 & 10.56 & 28.31 \\
\cline { 2 - 9 } & 5 & 8 & 12 & 15 & 5 & 8 & 12 & 15 \\
\cline { 2 - 9 } & 3.40 & 4.97 & 6.99 & 8.35 & 0.00 & 0.52 & 2.07 & 8.21 \\
\hline
\end{tabular}

Marketing and PHL assessment in Pink flesh guava in the distant markets

Guava produced in Bangalore is also transported to distant markets like Cochin in Kerala and Chennai in Tamil Nadu. The main marketing channel followed in the distant markets was:

\section{Producer $\rightarrow$ PHC $\rightarrow$ Distant Market WS $\rightarrow$ Retailer $\rightarrow$ Consumer}

The losses occurring during transit and at retailer's level are assessed and presented in Table $\mathbf{5}$.

Table 5. Transit and Retail level loss in Distant Markets

\begin{tabular}{|l|c|c|}
\hline Particulars & Kerala (\%) & Tamil Nadu (\%) \\
\hline Transit loss & 3.60 & 4.62 \\
\hline Retail level loss & 4.59 & 6.09 \\
\hline $\begin{array}{l}\text { Total loss at } \\
\text { distant market }\end{array}$ & 8.19 & 10.71 \\
\hline
\end{tabular}

Marketing and PHL assessment in Pink flesh guava in the distant markets - Kerala

Marketing practices followed in marketing of pink flesh guava and losses occurring at the wholesale (transit) and retailers' level (storage) in the distant market - Kerala were studied from 12 wholesalers in Mattancherry, Nettur and Ernakulam and 13 retailers in Varapuzha, Vyttila, Kadavantra, Thripunitura and Ernakulam.
The PHL at the wholesalers' level was observed to be 3.6 per cent mainly due to pressed and crushed fruits during transit. The retail level loss was 4.59 per cent which was mainly due to storage for more than two days resulting in decaying, rotting, yellowing etc. (Table 5). As may be seen from Table 6, average price received by the wholesaler was Rs. $29.92 / \mathrm{kg}$ with a margin of Rs.6.21/kg (20.95\%). The retailers received a price of Rs. $46.54 / \mathrm{kg}$ with a margin of Rs.16.35/kg (35.13\%).

\section{Marketing and PHL assessment in Pink flesh guava in the distant market - Chennai}

Marketing practices followed in marketing of pink flesh guava and losses occurring at the wholesale (transit) and retailers' level (storage) in the distant market - Chennai (Tamil Nadu) were studied with 9 wholesalers in Coimbeedu market. The retail level PHL was assessed from 18 retailers in MMDA market, Mylapore VMC, Alwarpet, Pondy Bazar, T.Nagar, West Mambalam, Thambaram, Chromepet, Pallavaram, Guindy, Saidapet, R.A. Puram, Royapettah and Zam Bazar market.

The PHL at the wholesalers' level was observed to be 4.62 per cent mainly due to pressed and crushed fruits during transit. The retail level loss was 6.09 per cent which was mainly due to pressing of fruits during handling (Table 5). The wholesaler, by selling the fruits to retailers at Rs.34.71/kg, received a margin of 22.91 per cent in trading of guava fruits. The retailers sold the guava fruits at Rs.66.53 and received a margin of 45.72 per cent (Table 6). 
Table 6. Marketing cost, price realized, intermediaries margin and producer's share in guava (Pink flesh) in distant markets (Rs/kg)

\begin{tabular}{|c|l|c|c|}
\hline Sl.No. & Particulars & Kerala & Tamil Nadu \\
\hline 1 & Selling price of PHC/Purchase price of Wholesaler & 20.83 & 24.00 \\
\hline & Marketing cost of WS & 2.88 & 2.75 \\
\hline & Margin of WS & $6.21(20.75 \%)$ & $7.96(22.91 \%)$ \\
\hline & Selling price of WS/Purchase price of Retailer & 29.92 & 34.71 \\
\hline & Marketing cost of Retailer & 0.27 & 1.40 \\
\hline & Margin of Retailer & $16.35(35.13 \%)$ & $30.42(45.72 \%)$ \\
\hline 2 & Selling price of Retailer /Consumer's price & 46.54 & 66.53 \\
\hline 3 & PHC's /Producer's share (\%) & 44.76 & 36.07 \\
\hline
\end{tabular}

Figures in parentheses are percentage to retailer's selling price
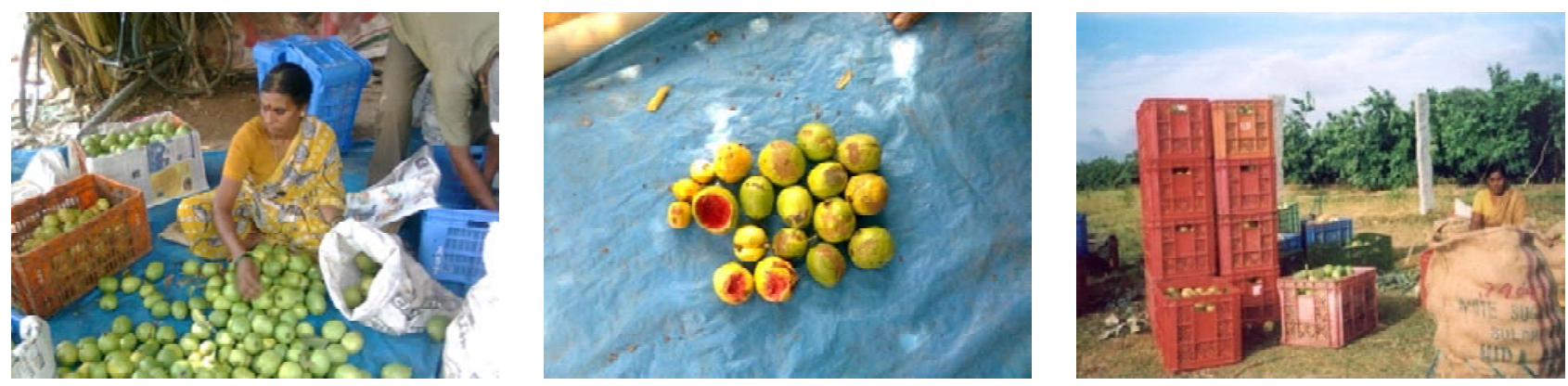

Fig. 1: Pink flesh guava harvested and sorted in Bangalore
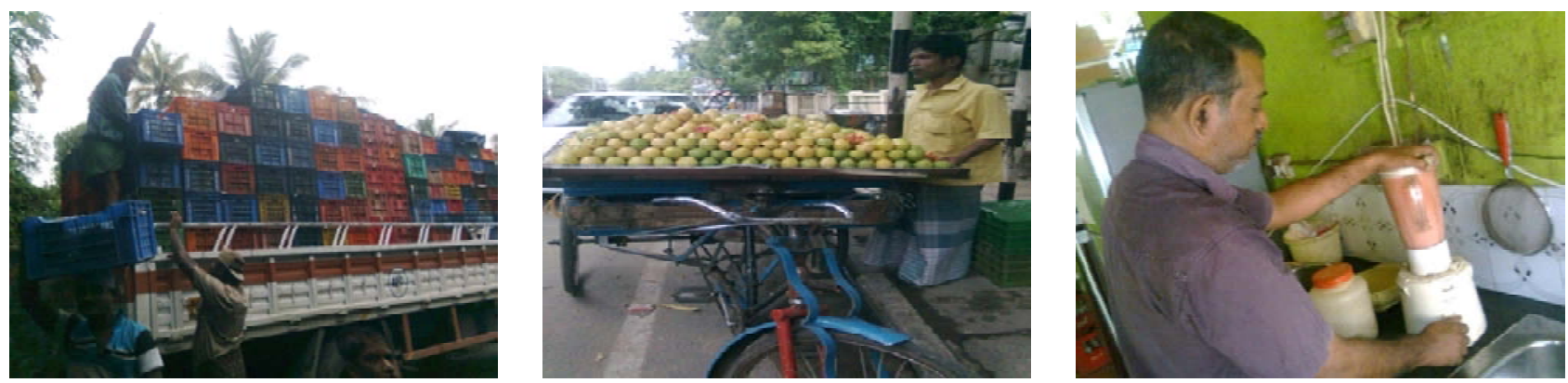

Fig. 2: Guava produced in Bangalore transported and sold in distant markets - Cochin and Chennai

\section{CONCLUSIONS}

- The price prevalent in the distant markets like Cochin and Chennai is much higher compared to local Bangalore market. Producers could get higher prices by transporting guava to distant markets like Chennai and Cochin. However, at present, producers are not transporting the fruits on their own; instead they are sending them through the agents of the distant market wholesalers. It was observed that the loss occurring at the distant markets worked out to 8-11 per cent. Considering the huge wholesaler's margin of 21-23 per cent and retailers' margin of 35-46 per cent in distant markets, there exists scope for the producers to venture into these markets.

- Overripe fruits account for about 4.16 per cent of the losses occurring at the field level. This damage due to over ripe fruits can be reduced by select harvest of fruits.

- The loss occurring at different stages of handling due to Styler end rot, Anthracnose, Canker, thrips attack etc. needs to be addressed. 
- The first application of Thiophanate methyl $(0.1 \%)$ or Carbendazim $(0.1 \%)$ or Chlorothalonil $(0.2 \%)$ at flower bud initiation stage; after 15 days the application of Ziride $(0.4 \%)$ or Zineb $(0.3 \%)$ and subsequently the third application of Mancozeb $(0.2 \%)$ or Carbendazim $(0.1 \%)$ or Thiophanate methyl $(0.1 \%)$ after 15 days the second application provides good control of the diseases.
- It was observed that after 4 days of storage, guava fruits lose weight to the extent of 6 per cent and the spoilage starts after 5 days. Hence, care should be taken to dispose of the fruits within five days of harvest. However, it was also observed that by storing the fruits at low temperature of $12^{\circ} \mathrm{C}$, the storage losses could be reduced.

\section{REFERENCES}

Gajanana, T.M., D. Sreenivasa Murthy and M. Sudha, 2011. Post harvest losses in fruits and vegetables in South India - A review of concepts and quantification of losses, Indian Food Packer, 65(6):178-187
Gajanana, T.M., D. Sreenivasa Murthy, A.K. Saxena, D.V.Sudhakar Rao, M.Sudha, and V. Dakshinamoorthy, 2015. Economic analysis of post harvest loss and marketing efficiency of guava (cv. Allahabad Safeda) in Karnataka, Journal of Horticultural Sciences, 10(1):70-73

(MS Received 25 September 2017, Revised 03 July 2018, Accepted 23 June 2019) 